\title{
Molecular identification of Haemonchus contortus in goats
}

\author{
L. M.Thamilbharathi ${ }^{1}$, R. Radhika ${ }^{2}$, M. N. Priya ${ }^{2}$, Binu K. Mani ${ }^{3}$, \\ K. Anbarasu ${ }^{1}$ and K. Devada ${ }^{4}$ \\ Department of Veterinary Parasitology, College of Veterinary and Animal Sciences \\ Kerala Veterinary and Animal Sciences University \\ Mannuthy, Thrissur, Kerala - 680651.
}

Citation: Thamilbharathi, L. M., Radhika, R., Priya, M. N., Binu, K. Mani., Anbarasu, K. and Devada, K. 2021. Molecular identification of Haemonchus contortus in goats. J. Vet. Anim. Sci. 52(2): 183-186. DOI: https://doi.org/10.51966/jvas.2021.52.2.183-186

Received : 02.01.2021

Accepted : 05.02.2021

Published : 01.06.2021

\begin{abstract}
Haemonchus contortus commonly called the stomach worm or wire worm of ruminants inhabits the abomasum and is considered to be one of the economically important gastrointestinal strongyles in goats. In the present study, $\mathrm{H}$. contortus was identified by PCR using the primers targeting partial 5.8S and partial internal transcribed spacer region 2 (ITS-2). Adult worms were identified morphologically and genomic DNA was extracted using DNeasy Blood and Tissue kit (QIAGEN, Germany). Gradient PCR protocol was standardised using the extracted genomic DNA. Ten-fold serial dilution of adult DNA was used to analyse the minimum detection limit and the products were amplified upto the tenth dilution. Cross reaction of primer sets was checked using the DNA extracted from predominant adult srongyles like Oesophagostomum columbianum and Trichostrongylus colubriformis and no cross reaction was seen at the optimum annealing temperature $\left(60.7^{\circ} \mathrm{C}\right)$.
\end{abstract}

Keywords: Haemonchus contortus, goats, PCR, ITS-2

Haemonchus contortus belong to the Trichostrongylidae family and are commonly called the stomach worms or wire worms of ruminants. The adult worms attach to the abomasal mucosa of small ruminants and due to its haematophagus nature it causes anaemia, jowl oedema and even death in young ones. Adult worms are identified based on morphological features. But identification of nematode species based on features of the strongyle egg is difficult during coprological examination. Coproculture aids in species identification but it takes seven to ten days to identify the infective larvae. Hence, molecular identification was undertaken in this study as a tool for species

1.MVSc scholar and corresponding author: email: thamil.vet93@gmail.com Phone No. 9500387316

2. Assistant Professor

3. Assistant Professor, Department of Veterinary Microbiology

4. Professor and head

Copyright: (C) 2021 L. M.Thamilbharathi et al. This is an open access article distributed under the terms of the Creative Commons Attribution 4.0 International License (http://creativecommons.org/licenses/by/4.0/), which permits unrestricted use, distribution, and reproduction in any medium, provided the original author and source are credited. 
level identification.

Abomasum of 19 animals brought for slaughter at the Corporation slaughter house, Kuriachira, Thrissur was collected and taken to the laboratory for further processing. An incision was made at the greater curvature of the abomasum and the contents were carefully washed on to a container. Abomasal contents were washed several times until the contents were clear so that the worms could be visualized easily. Adult worms were collected and stored in $1 \mathrm{X}$ phosphate buffer solution (PBS) at $-20^{\circ} \mathrm{C}$. About three to five adult $H$. contortus worms were used for extracting genomic DNA using DNeasy Blood and Tissue kit (QIAGEN, Germany). The DNA thus obtained was stored at $-20^{\circ} \mathrm{C}$ for further use. The concentration and purity of DNA extracted were assessed with nanodrop spectrophotometer and it was found to be $74 \mathrm{ng} / \mu \mathrm{L}$. Primer sets targeting partial $5.8 S$ and ITS-2 regions were designed using online software "Primer 3" Input Version 0.4.0, its suitability checked using the online software 'Sequence Manipulation Suite' Version 2 and its specificity checked using the software NCBI BLAST (www.ncbi.nlm.nih.gov). The designed forward and reverse primers were 5'-CACGAATTGCAGACGCTTAGA-3' and 3'TCGTCGCCATACATGTCACT-5', respectively. Gradient polymerase chain reaction was standardised with initial denaturation at $94^{\circ} \mathrm{C}$ for $5 \mathrm{~min}$ followed by 39 cycles of denaturation (94 ${ }^{\circ} \mathrm{C}$ for $\left.30 \mathrm{~s}\right)$, annealing (57 to $63^{\circ} \mathrm{C}$ for $30 \mathrm{~s}$ ), extension ( $72{ }^{\circ} \mathrm{C}$ for $30 \mathrm{~s}$ ) and final extension at $72^{\circ} \mathrm{C}$ for $10 \mathrm{~min}$. The composition of reaction mixture is given in Table 1.
After performing gradient PCR, the amplicons were subjected to agarose gel electrophoresis in 1.5 per cent agarose gel at $80 \mathrm{~V}, 400 \mathrm{~mA}$ for $35 \mathrm{~min}$ and the gel was visualised in Gel Doc ${ }^{\mathrm{TM}} \mathrm{EZ}$ imager and documented using Image lab software. The amplicons were purified and sequenced at AgriGenom labs Private Limited, Cochin using Sanger's di-deoxy nucleotide chain termination method. Bidirectional sequencing was done using both forward and reverse primers. Sensitivity and specificity of the primers were also assessed.

The adult worms were identified morphologically based on their characteristics like the presence of cervical papillae at their head end with small buccal cavity. The male tail end had a well developed bursa with elongate lateral lobes which was supported by an asymmetrical dorsal lobe. The dorsal lobe was placed on the left lateral lobe which was supported by an inverted $Y$ shaped dorsal ray. The female worm had a barber's pole appearance which was due the coiling of white ovaries that were wound around the red intestine (Soulsby, 1982). Out of 19 abomasa collected, 12 were found to be positive for $H$. contortus which accounted for a 63.1 per cent infection in goats. Haemonchus contortus has been identified as the predominant strongyle species in goats in different places including Kerala (Deepa, 2005), North-West India (Kumar et al., 2008) Malaysia (Chandrawathani et al., 2009), Kashmir (Irfan-ur-Rauf-Tak et al., 2013) and Ethiopia (Chalchisa et al., 2015).

Table 1. Composition of reaction mix

\begin{tabular}{|c|c|}
\hline Components & Quantity ( $\mu L)$ \\
\hline $10 \times$ PCR buffer (without $\mathrm{MgCl}_{2}$ ) & 2.5 \\
\hline dNTP (10 mM each) & $0.50(200 \mu \mathrm{M}$ each $)$ \\
\hline Primer forward & 1 (10 pmol) \\
\hline Primer reverse & $1(10 \mathrm{pmol})$ \\
\hline Magnesium chloride (25 mM) & $1.50(1.5 \mathrm{mM})$ \\
\hline Taq polymerase (5 IU/ $\mu \mathrm{L})$ & $0.20(1 U)$ \\
\hline DNA template & 5 \\
\hline Nuclease free water & 13.3 \\
\hline Total & 25 \\
\hline
\end{tabular}

184 Molecular identification of Haemonchus contortus in.. 
Single specific amplicons of $\sim 300 \mathrm{bp}$ size were obtained at all the annealing temperatures i.e., 57 to $63^{\circ} \mathrm{C}$ in gradient PCR. Yin et al. (2013) amplified $H$. contortus DNA targeting ITS-2 region and the products were obtained at $231 \mathrm{bp}$. The obtained sequences were subjected to homology analysis and 100 per cent identity obtained with other published $H$. contortus 5.8S rRNA gene and ITS sequences. The sequences were submitted to GenBank and assigned with accession number MW341458.1.

The sensitivity of $H$. contortus primer sets was checked using ten-fold serial dilution and the ability of primers to amplify minimum DNA concentration was analysed. The initial concentration of DNA used for sensitivity study was $4.7 \mathrm{ng} / \mu \mathrm{L}$ and ten-fold serial dilution was performed. PCR products were amplified upto tenth dilution which showed that the primer pairs could amplify DNA with minimum concentration of $4.7 \mathrm{ag} / \mu \mathrm{L}$ (attogram per microlitre) (Fig. 1).

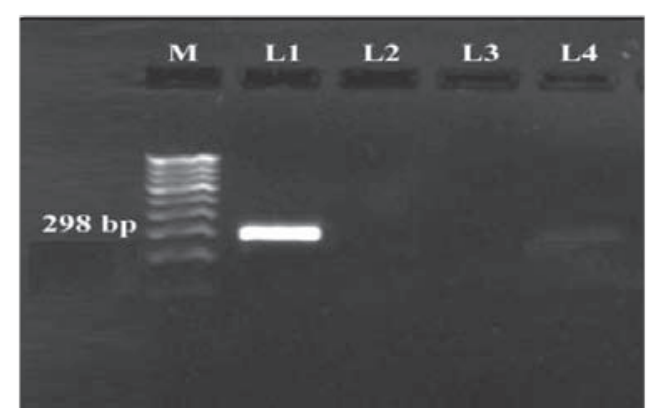

Fig. 1 Amplicons of $\boldsymbol{H}$. contortus

Lane M: 100 bp ladder

Lane 1-10: Ten-fold serial dilution H. contortus DNA

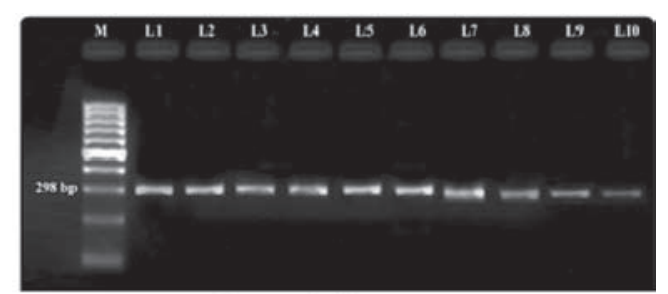

Fig. 2 Specificity of $\boldsymbol{H}$. contortus primer Lane M: 100 bp ladder

Land 1: Adult $H$. contortus amplicon

Lane 2, 3: Adult O.columbianum and T. colubriformis DNA

Lane 4: NTC (No Template Control)
The specificity of primer was cross checked with DNA of other important strongyles like Oesophagostomum columbianum and Trichostrongylus colubriformis to detect cross amplification between species. Non-specific amplification was not detected between these species (Fig. 2), thus proving the species specificity of primers.

\section{Summary}

The study forms the basis for developing copro-polymerase chain reaction for detecting $H$. contortus infection in goats. Specific detection of this pathogen from clinical samples would aid in initiating timely control measures.

\section{Acknowledgement}

This study has been carried out as part of Master Research program and the financial support provided by Kerala Veterinary and Animal Sciences University is acknowledged.

\section{References}

Chalchisa N., Muktar. Y. and Keffale. M. 2015. Prevalence of gastrointestinal strongyles parasites of small ruminants in and around Haramaya, Ethiopia. Middle-E. J. Sci. Res. 23: 2833-2840.

Chandrawathani, P., Nurulaini, R., Adnan, M., Premalaatha, B., Khadijah, S., Jamnah, O., Zaini, C.M., Khor, S.K. and Zawida, Z. 2009. A survey of parasitic infection on small ruminant farms in Kinta and Hilir Perak districts, Perak, Malaysia. Trop. Biomed. 26: 11-15.

Deepa, C.K. 2005. Anthelmintic resistance in gastrointestinal nematodes of goats. M.V.Sc thesis, College of Veterinary and Animal SciencesMannuthy, Thrissur.

Irfan-ur-Rauf Tak, Chisti, M.Z. and Ahmad, F. 2013. Epidemiological studies of abomasal nematodes of sheep of Kashmir Valley with particular reference to Haemonchus contortus. Nat. Sci. 11: 34-39. 
Kumar, R.R., Yaday, C., Garg, R., Banerjee, P.S. and Vatsya, S. 2008. Prevalence of gastrointestinal nematodes in sheep and goats in some parts of north-west India. The Indian J. Ani. Sci.78: 124446.

Soulsby, E. J. L. 1982. Helminths, arthropods and protozoa of domesticated animals. ( $7^{\text {th }}$ Ed.). Balliere, Tindall, London. $72 p$.
Yin, F., Gasser, R.B., Li, F., Bao, M., Huang, W., Zou, F., Zhao, G., Wang, C., Yang, X., Zhou, Y. and Zhao, J. 2013. Genetic variability within and among Haemonchus contortus isolates from goats and sheep in China. Parasites \& vectors, 6: 279 . 